\title{
PEASANTS AND FEUDALISM: THE RELEVANCE OF HISTORICAL EVENTS WITH THE LIFE SKILLS CURRICULUM
}

\author{
Siskandar ${ }^{1}$
}

\begin{abstract}
The life skills values prevalent among the peasants' society in the past can be integrated into the content of life skills subject in the historical learning given to students. The expansion of plant products export in the era of Dutch Colonial was significant in the emergence of some changes in the socio-economic life of the peasant and villagers in Java. They were further immersed into the flow of commercialism. The issue in this article is how the response of the farmers to those changes. As an object of observation, this article took the object of study of village areas in Afedeeling Purwerodjo in the beginning of the twentieth century. The methodology used in this article was historical method involving the processes of heuristic, critiques of resources, interpretation, and historiography.

The theoretical framework used in this article was dialectics between the assumption that the change of the socio-economic life in the villages into commercialism was a prolong nightmare for the villagers and the assumption that the changed socioeconomic life of the villages into commercialism brought new economic opportunities for the villagers. The conclusion was commercialism resulted in rationality and prosperity for the farmers. The peasants would spend their time and energy more efficiently to exploit the new opportunities given. The rational considerations were more determining than the social motivation in terms of decision making. The peasants had the life skills to create beneficial alternative economic resources to support their lives in the middle of a greater flow of foreign plantation commercialism.
\end{abstract}

Key words: life skills of the peasants, peasant in the Dutch Colonial, rationalit of peasants

\section{Introduction}

In the social science curriculum published by the Center of Curriculum Research and Development, Ministry of National education, 2007, it is stated that: learning in Social Science Education is to give students the values of life skills to cope with the problems they face. Life skills are not a subject but an education which is integrated into a subject. The philo sophical base used is the philosophy of teaching practical intelligence and the ability to solve problems faced by the students themselves. The values of life skills received by students

${ }^{1}$ Dr. Siskandar, Lecturer of Universitas Negeri Semarang (Semarang State University). This article has been reviewed by Prof. Dr. Nina Herlina Lubis (Padjadjaran University, Bandung, Indonesia), and Prof. Helius Sjamsudin, MA (Universitas Pendidikan Indonesia) 
become a tool for them to solve the problems they face. In the problem solving process there is an inquiry of new information. This new information can be the knowledge for students in positioning themselves to the changes either at present or in the future. The values of life skills learned contain practical values.

One of the subjects of social science which has the mission to buil students' characters is history subject. The past events introduced by the subject will build collective memory in the minds of students. The collective memory will be attached to the students not only as a-must-to-memorize knowledge, but also as the source for historical values. Through historical learning, it is expected that students will be able to make a rational and wise decision and appreciate good and bad examples of the past events. Therefore, history subject contains a dimension of valueable education in an attempt of building students' characteristics.

History bears with it educative usefunction because it can give wisdom for the people learning it, what Bacon formulated as "histories make man wise". History pays attention to the past which cannot be separated from the present, because the spirit and aim of learning history is the value of the present. This is also implicitly contained in Croce's words "all history is contemporary history" which was later developed by Carr that history is "unending dialogue between the present and the past". From the statements mentioned above, it can be concluded that if we can project our past time to the present, we can find educative meaning from history.

History has function of inspiring because it can give inspiration to us through its ideas and concepts which can be used to solve the present problems, especially ones related to the spirit of creating an identity as a nation and national development. In addition, history contains in it a re-creative use because by reading historical writings we would feel as if we did "a historical visit" because we can pass the time and place borders towards the past to "follow" what had happened. Meanwhile, the instructive use of history is to support certain field of skills.

In its relation to educative and inspiring functions, it can be said that history has a strong relation with education in general and nation character building in particular. Through history, the inheritance of the values from the past to the present generation can be done. This value inheritance, which will grow historical awareness, in turn, can be benefited for nation character building.

The social historical events of the past, which take the forms of social changes and adaptive behaviors among the society who experienced the changes, can be integrated into the content of life skills in the historical learning subject given to students. Thus, when the recent events showed the tendency of similarities with the events in the history subject at school such as unemployment, poverty, crime, labor strike, land dispute, mass riot, and various multidimensional crisis phenomena, then students will not find difficulties in understanding, analyzing, and positioning themselves to what they have to choose and do. 
In 1870 , the Dutch colonial government issued the Agriculture Law (Agrarische Wet) which regulated the land use in Java. In essence, this law was an attempt of the the Dutch colonial government to free the land from the traditional binds so that the plantation entrepreneur could freely take control of the farmers' land by conducting an individual contract system.

The feudal system of the traditional land ownership in Java positioned the feudal regents as the owners of the whole land including the workers (the citizens) who live on the land under their authority. Citizens in the context of workers were only cultivating labors who would receive a share of the harvest yields after having been discounted for the feudal authority. The plantation party had to rent the land from the feudal authority, and they even had to give premise in a great number to get the workers. In terms of the rent rate, the plantation party could not take part in determining it since what they faced were the "priyayi" (high class Javanese), not the citizens or "wong cilik" (lower class people).

The 1870 Agriculture Law brought transformation the feudal system of land ownership in the areas colonized by the Dutch colonial government in Java. In the $19^{\text {th }}$ century, the control of Java areas was divided into three; they were: areas which still belonged to the existing traditional kingdoms (Vorstenlanden); areas belonged to individuals, either foreign or local, who, because of their contributions to the kingdom received a gift of some land from the kingdom (Partikelirlanden); and areas controlled by the Dutch colonial government (Governmentlanden). The traditional regents in these areas were positioned as the employees of the colonial government and received monthly payment from the government's cash as the compensation for their income to the cash (in natura) coming from the harvest yields of the farms in their areas. The farms were distributed to the citizens as inheritable land possession. The citizens were imposed with requirements to receive land sharing, that is they had to pay for the land tax to the Dutch colonial government and had to give their permission if the land was to be rented by private plantation.

The transformation brought about by the colonial government had given easiness to the plantation parties to get rid of unnecessary expenditure in an attempt of achieving the aim of commercialization, considering that starting from that point what was faced by the plantation owners were no longer the traditional Javanese feudal authorities but the local citizens. The implementation of Agriculture laws made the exported plants experience progressive development (Kartodirdjo, 1991: 70-112). The expansion of the exported plant production was a significant process in the Javanese rural areas, considering the intensive increase of Western influence on the villages. The villagers or farmers were deeply immersed into the commercialization.

Based on the explanation above, the next emerging issue is how the response of the farmers was towards those transformations. As the observation laboratory, this article took an object of study in the villages of AFEDEELING Purworejo in the beginning of the twentieth century. 
HISTORIA:

International Journal of History Education, Vol. XI, No. 1 (June 2010)

\section{The Concepts of Feudalism and Feudal Society}

Feudalism is a governmental system where the leader is usually a nobleman owning a great number of accomplices from the same background but with lower level usually called vazal. These vazals are obliged to pay tributes to their masters. The vazals in turn receive tributes from their own accomplices. Therefore, a very hierarchical structure in the shape of a pyramid emerges.

Feudal, is a term used in the beginning of the modern era, which is the $17^{\text {th }}$ century, to refer to an experience of the middle century European political system. The political system established at that era was a combination of either legal or illegal military people or warlords, landlords, noblemen, kings, which resulted in an exclusive hierarchy in the society: there were a king, noblemen, and also servants and slaves (vassals). Still, the keyword is a hierarchy.

The term feudalism comes from Frankis (old French) fehu-ód, feod, feud, which means a loan, more particular, rented land, which contains political meaning. The antonym is self-ownership. In legal terms, the traditional law of feodum resembles what is called as tanah gumantung, gaduh or paratantra, while allod is similar to tanah yasan, yosobondo, or syatantra.

Feodum or land loan as such emerged in the past in a great number in the Western European countries which occured simultaneously with the event of decentralization of Frankis Kingdom after the Great Karen. Thus, Frankis Kingdom was born after the sink of the Rome Imperial. In the Roman law, it was mentioned that the great awareness of an individual absolute possession is guaranteed by various regulations. The Imperial Rome was in the form of a highly centralized government and was based on capitalism which became stronger since the era of the Great Diocletinus King (286-305 DC).

In the middle ages, there was almost no money circulation and it was in general impossible to pay a body of a government or a military man, what is more to administer a centralized country administration. Therefore, it was in an attempt to administer common people's security and to prevent from riots that some ethnic organizations from the era before the Rome were rejuvenated. In the ethnic organization, collective possession, not the absolute individual possession, was very strong.

In the book of "Kepemimpinan Jawa", Hans Antlov (2000) defines feudal society as a "society arranged based on a large land ownership. Feudal system is a social system based on wide landownership. The landlords were the kings (the great king or kaisar)". Antlov and Cederroth then explain that "since the land he owns is really large, it is impossible for a king to manage his own land. If he does not want to lose all his land, he has to share the land with others who are able to be governed in the feudal bind (in the feudal contract). With this contract, the higher level authority or the feudal master shares (gives) a part of his land to the king or the lower-level authority in Indonesia called Bupati (regent), which is called vassal in Europe (land user of the landlord's land). In return, the lower 
level king has to give his loyalty to the higher level king by means of forming a group of troops and giving tributes. When the higher level king wants to do an expansion, the lower level king with his troops will follow. To cultivate the land, the lower level king rents the land to the farmers; in Indonesia (Java) it can be rented to the rural heads or bekel".

Land ownership in Java in the feudal era is that the King as the God representative in the world (or even the King himself admitted to be a God) was the owner of the land and the people who lived on it. The King lent his land to the regents to cultivate. The regents assigned the bekels to cultivate the rented land. The bekels coordinated the villagers as farmers to cultivate the land. In the harvest time, a part of the yields was given to the kingdom as the Kings' rights, another part was given to the regents as compensation or payment, another part was for the bekels, and the rest of it went to the village granaries as food supply for the whole villagers until the next harvest time. Therefore, the villagers' agriculture system in Java in the feudal era was subsistent, or was only intended to fulfill the needs for food with non-profit motives (Bremen, 1986).

The entry of commercial economic system in the era of the Dutch colonial government into the subsistent economic system of the farmer society in the Javanese villages is a theme which has attracted historians and other relevant parties to research, discuss, and write scientifically about the colonial period in Indonesia. Some of their writings which can be made as comparison for this research are as follows:

Masyarakat Desa dalam Perubahan Zaman, Sejarah Deferensi Sosial di Jawa 1830-1980, by Frans Husken (1998). In this writing, a paradigm of the impact of the implementation of commercial economic system by the plantation industries into the ecology of the agriculture society, which was still under the subsistent economic system, was in fact impeding the success path of the plantation owners. This was due to the fact that the plantation parties running the commercial economic system aggressively made the villagers where the plantation took place as tunakisma (farmers without land to cultivate), so that the plantation owners ought to cope with the problem of labor payment which tended to be increasingly higher according to the developing economic situation considering the fact that the villagers did not have other economic resources.

Di Bawah Cerobong Asap Pabrik Gula, a compilation of editorials by Hiroyosi Kano et al (1996). In this work, the positive function of the entry of commercial economic system (in the form of plantation) into the subsistent economic system (traditional agriculture) of a society is presented. The production activities in the plantation would result in the increasing number of paid jobs as the alternative economic opportunity with more certain, continual, and probably higher payment than the payment earned from traditional agriculture. The indicator of guaranteed socio-economic life of villagers with the existence of commercial plantation could be seen from the increasing number of population even though in the increasingly smaller land for traditional agriculture. 
Sejarah Perkebunan di Indonesia, a socio-economic study, written by Sartono Kartodirdjo and Djoko suryo (1991). This writing proposes an alternative theoretical framework to be used to reconstruct the history of the entry of commercial economic system into the traditional subsistent agricultural system; that is the implication of the emergence of a kind of "job market". The argument based on the theoretical framework is that the labor values in that tend to be subsistent traditional agriculture was irrational. The existence of plantation industries made the labor more valuable economically as an alternative to support daily life necessities in addition to the agriculture that could still be conducted.

"Kerja Wajib Sampai Kerja Upahan: Penguasaan Tenaga Kerja oleh Perkebunan di Yogyakarta, 1830-1930," by Sukarto (1997: 26-43). The entry of capitalist plantation economy along with all its domination into the Yogyakarta Sultanate had changed the constellation of the dynamics of the economic structure in the villages of the area. The subsistent local economic system (self necessities fulfillment) tended to be disadvantaged by the capitalist plantation economic system oriented towards maximum profit gain. The land and the labors became the meeting point from the two different interests. The attraction on land and labors in the "arena" between the interest of the villagers and the interest of the plantation brought a significant influence for the social transformations in the villages of Yogyakarta.

\section{Commercialism and Rationality of the Farmers}

Commercialism of the plantation economy in the colonial era certainly created striking differences with the local economic system. The former followed the commercial economic system which oriented towards continual maximum profit gain; whereas the latter was traditional, oriented towards subsistence. The two working systems are called dualistic economic system by Boeke (Boeke \& Burger, 1973). According to Boeke, the economic relationship will be capitalistic. The modern economic party used modern economic tools in their activities (contracts, money, purchase, etc.), built an organization and enterprise according to their wants, and attracted other parties to adapt with them.

Land and labors availability were two significant industrial factors and the bases for the farmers' economy. For the plantation, both factors were a must. Therefore, this issue is interesting to discuss, especially since land and labors became the meeting point of the two different interests.

The next problem to come up is the socio-economic condition of the villagers which was resulted from the transformations. Some of the historical economy researchers assumed that the socio-economic life that turned into commercial economy for villages was a prolong nightmare. Agriculture as the backbone for the farmers' economy experienced involution, so that they were forced to share the economic tokens, one for all and all for one, as the solution (Geertz, 1983: 
102). When the solution was impossible to implement, the only solution would be to fight against it or even to take a rebellion (Scoot, 2000: 82).

Another assumption was that commercialism had indeed caused rationality and prosperity among the farmers (Popkin, 1979: 64). The transformations occurred were thought to also bring about new economic opportunities for the villagers. The farmers would use their time and efforts more efficiently to take advantage of the new opportunities. According to the assumption, rational considerations were more determining than social motivation in decision making.

\section{Research Method}

Basically, method is a way used to reach a goal. The main aim of this research is to solve a problem; therefore, the method used should be relevant with the problems formulated. If the problems raised in this article are historical problems with the past as the object of the study, then it will be more appropriate to use historical writing method to solve the proposed problems.

Historical method is a process of studying and analyzing the truth of a record of the past event to be used as the material to compose a historical writing on the past chronologically and systematically. Historical method is a process conducted by historians in an attempt of searching for, gathering, testing, selecting, and tracking historical facts, and translating them into the right order (Suryomihardjo, 1979: 133).

The historical methods referred to are as follows (Gilbert \& Garraghan, 1957: 33):

1. Heuristic or the searching process to find historical resources, either primary or secondary resources. Heuristic activities on primary resources were focused on the study of the Dutch colonial government's archives related to the social transformations in Purworedjo in the beginning of the twentieth century caused by the intensive industrialization (sugar industries) in the area. In addition, the activities were also focused on other historical facts relevant to the problems raised in this research. The activities were conducted at the National Archives the Republic of Indonesia in Jakarta. The heuristic activities on the secondary resources were focused on the literature studies relevant to the problems raised in this research. The function of the secondary resources was as the supporting material and comparison for both the study of historical stories under research and the analysis of the problems raised in the research. The activities were also conducted in the same place.

2. Critiques of resources, a selection process on the appropriateness of the primary resources found. This critique of resources activity was conducted in two stages; they are external and internal critiques. The external critique was done to the physical form of the documents found, whether they were original or not. It was conducted by looking at the physical characteristics 
of the documents found; which are the type of paper used, the writing model used, the language used, the year written on the documents, and the legal evidence of the documents. The legal sign referred to is, for example, in the forms of signatures, stamps, headers, and logos or certain symbols used. All the physical characteristics of the resources found should have the nuances matched to the era of the events under observation. Next is the internal critique, which focuses on the content of the historical resources which have passed the external critique. The content of the resources should be observed in terms of the appropriateness of the content. The data of the historical resources which have passed both the internal and external critiques are facts or raw material for historical writing.

3. Interpretation is the interpreting process and the arrangement of the obtained facts based on the cause-effect relationship which is in accordance to the chronological order of the events, so that a rational or logical chronological order of the event is obtained.

4. Historiography is an attempt to express and present the chronological order of events obtained into a story or history in the forms of historical writing. In this attempt, the writer used the aids in the forms of writings by other writers relevant to the theme raised in this research, as the material to support and as comparison in both composing the reconstruction of events and explaining the problems raised in this research.

\section{Results of the Research}

\section{The Relevance of Historical Events with the Life Skills Curriculum}

The basic difference between this writing and the writing by other writers aforementioned in the previous subchapter is that this writing seeks to find how the life skills of the peasants in surviving with the plantation economic commercialism. It is expected that it can be later used as the content of life skills education values in history subject.

In the history education curriculum published by the Center of Curriculum Research and Development in 2007 it was determined that the characteristics of historical learning should be:

a. Containing heroic values, exemplary, pioneering, patriotism, nationalism, and the spirit of not easily giving up which become the bases for the character building process of the students;

b. Containing knowledge on nations' civilization, including Indonesian civilization. Learning material as such is the principle learning material for the process of the shaping and the creation of Indonesian civilization in the future;

c. Growing the awareness of unity and friendship and solidarity to be the adhesive power of the nation whenever the issue of disintegration threatens. 
d. Rich of the teaching of moral and wisdom useful for coping with multidimensional crises faced in daily life;

e. Useful in growing and developing responsibility to maintain the balance and the preservation of the environment.

The goal of historical learning is not merely to transfer knowledge, but also to transfer values, not only to teach students to become clever but also to teach the young generation to be able to take examples and lessons from the experience of their ancestors. The didactic value of the historical knowledge in the current education is in addition to generate historical awareness is also to improve rationalization process and to release the mythological thoughts.

Life skills curriculum puts forward the following aspects: (1) the relevant ability for the students to gain, (2) teaching material appropriate with the developmental level of the students, (3) learning activities and other students' activities to reach competences, (4) appropriate facilities, equipment, and learning resources, and (5) applicable skills in the life of the students. Life skills will be more meaningful if the learning activities are designed to give positive impacts to the students in helping them to cope with their problems by proactively and reactively finding solutions for the problems (Balitbang Puskur Depdiknas, 2007).

Based on the statements above, schools/regions have large authorities to develop and administer education appropriate with the condition of the students, the school, the potency and the needs of the region. Related to that, the various ethnics with various cultures (customs, procedures, language, art, crafts, regional skills, etc.) existing in Indonesia are the unique characteristics that enrich the nation life. The diversity needs to be maintained and developed by maintaining the values of Indonesia as a nation through life skills education. The introduction to the environment, social and cultural conditions to the students enable them to be more familiar with their environment. The introduction and the development of the environment through education are oriented to support the improvement of the quality human resources, and eventually to improve the students' competence.

The policy related to the inclusion of life skills education in the content standard and graduate competency standard was based on the fact that education does not merely pursue knowledge but also the development of skills, attitude, and certain values which can be reflected in the life of the students. Schools as the place to administer education are part of the society. Therefore, life skills education program at school needs to give board insights to the students in terms of certain skills related to students' daily life experiences. To facilitate the administration of life skills education program there needs to be a general development model to help teachers/schools to develop the life skills content in the learning process. Life skills education is not an independent subject but it is integrated to other subjects, so that life skills education can be a part of all subjects. 
Education develops students' potentials to be brave in coping with problems without feeling depressed, to be able and desirable and happy to develop themselves to be excellent human beings. Education drives students to take care of themselves while intensifying their relationship with God, the society, and the environment. Therefore, it is clear that life skills education helps teachers/ schools in teaching various life skills to students by combining the general and specific potentials to cope with and solve their problems in the life of their society and their environment, both locally and globally.

\section{Purworedjo in the Beginning of the Twentieth Century}

Purworedjo in the beginning of the twentieth century was a regency (Afdeeling) situated under the administration of Kedu Residency (Nijhoff, 1917: 103), and was a fertile agriculture area (Geertz, 1983: 103). The majority of the village areas at Afdeeling Purworejo positioned rice field agriculture as the economic pillar. In general, the rice field in Purworejo could be categorized into three kinds: rice field (with one-year-long irrigation), half technical rice field (with irrigation only in the rainy season), and rain cistern ricefield.

In the beginning of the twentieth century, the composition of farmers at Purweredjo was as follows: (1) farmers without lands or farm workers as much as $40.15 \%$, (2) farmers owning land less than 1 bau as much as $41.15 \%$, (3) rich farmers with land as large as 6 bau as much as $0.99 \%$, and (4) farmers who owned land as large as between 1 to 4 bau as much as $17.30 \%$. in general, rice agriculture in Purweredjo had twice harvest times in a year, that is harvest time in the dry season (for technical rice field) and harvest time in the rainy season (for technical rice field, half technical, or rain cistern rice field).

Rice field in Purworedjo as a whole was 41.122 bau $\left(1 \mathrm{bau}=7,096 \mathrm{~m}^{2}\right)$. At that time, there were two quite big private sugar factories in Purworedjo: Purworedjo and Rembun sugar factories (Kartodirdjo, 1977: 195), and as a whole the agriculture land available until 1930 was used by the two sugar factories in Purworedjo for sugar tree plantation as large as 26,737 bau (64\%) (Kartodirdjo, 1997: 197-198). It means that the agriculture land was only $36 \%$ left from the total area of the available agriculture land.

The agriculture land in Purworedjo could be harvested twice a year, in the rainy and dry season. Rice yields of the two different seasons were different since rice planting in the dry season could only be done in the technical rice field. During the last three decades of the nineteenth century, rice production in Purworedjo was not really high; in fact there was a shortcoming for rice so that the government had to import it from outside Purworedjo regency. In 1875, the rice produced in Purworedjo was only as much as 210,000 yokes (as much as $61.76 \mathrm{~kg}$ ), and the average rice harvest failure in the regency reached 18\% (Kartodirdjo, 1977: 197198). The government's effort to cover for the rice shortcoming in Purworedjo was by importing rice from Semarang as much as 17,400 yokes; however, based on the reports of food commission in Purworedjo it was stated that the region was 
still in need of rice supply for as much as 120,00o yokes in 1875 .

From 1902 to 1903, the area of rice field in Purworedjo for the rainy season was as much as 41,122 bau and for the dry season as much as 26,737 bau. At that time, every bau was estimated to be as much as 26 yokes; thus, in a year the average total rice production in Purworedjo reached 1,763,334 yokes. If the total production was divided with the number of Purworedjo citizens which reached 540,000 people, then each person received 3.27 yokes in average. The average number of rice received per citizen slightly decreased from 1916-1920 as much as 0.10 yoke or became 3.17 yokes (Gelderen, 1912: 225-247).

One of the causing factors of the decrease was the increasing slope of the quality of the rice production in every bau. The average results per bau during 1916-1920 and 1922-1927 were 25.24 and 24.55 yokes respectively. Thus, there was a fluctuation as much as 0.69 yoke or $2.7 \%$ from the first period compared to the period of $1892-1893$ which experienced a fluctuation of 1.99 or $7.4 \%$. The fluctuation in the rice production during the periods of 1916-1920 and 19201927 occurred in five districts of Purworedjo regencies; they were Loano District, Cangkep District, Kemiri District, Pituruh District, and Purwodadi District. In Purworedjo and Kutoarjo Districts the fluctuations were actually as much as 4.06 and 1.06 yokes respectively.

Table 1. Rice Crops per bau in Purworedjo Afdeeling:

\begin{tabular}{l|c|c|c|c}
\hline Districts & $\begin{array}{c}\text { 1892-1893 } \\
\text { (yokes of rice) }\end{array}$ & $\begin{array}{c}\text { 1916-1920 } \\
\text { (yokes of rice) }\end{array}$ & $\begin{array}{c}\text { 1922-1927 } \\
\text { (yokes of rice) }\end{array}$ & $\begin{array}{c}\text { Fluctuation } \\
\text { (yokes of rice) }\end{array}$ \\
\hline Purworedjo & - & 16.26 & 30.37 & +4.06 \\
Loano & - & 21.29 & 19.85 & -1.44 \\
Cangkep & - & 26.05 & 24.57 & -1.58 \\
Kuoarjo & 17.80 & 22.32 & 23.28 & +1.06 \\
Kemiri & 34.50 & 24.03 & 23.37 & -0.66 \\
Pituruh & 24.17 & 30.40 & 27.79 & -2.61 \\
Purwodadi & 20.68 & 27.98 & 22.55 & -0.37 \\
\hline Average & 26.54 & 25.55 & 24.55 & -0.69 \\
\hline
\end{tabular}

Source: Sajogyo and W. L. (Coller, 1986: 181).

The planting of wet rice was the economic structure foundation of the villagers in Afdeeling Purworedjo in the beginning of the twentieth century; however, it does not mean that the agriculture in the area was limited to rice field. The number of dry soil which was planted and cultivated like rice field reaching $15 \%$ in the rainy season and as much as $43 \%$ in the dry season had contributed to the crops other than rice (Bijlage, 2: 6-7). The kind of plants planted in the dry soil was dominated by gogo rice (red rice) and the usual crops planted in the dry soil (palawija) (Bijlage, 2: 6-7).

The main plant for the palawija in the rainy season covered corns, vegetables, soybean, and even tobacco or sugar cane tree; whereas in the dry season 
the plants were corns, sweet potato, and cassava (Bijlage, 2: 14-15). Since 1870, palawija plants started to develop due to the elimination of indigo plantation which gave chances for farmers to plant more palawija.

In the beginning of the twentieth century, the dry soil in Purworedjo which was planted by cassava and corns reached 8,948 bau and 4,699 bau respectively (Bijlage, 2: 14-15). The number of cassava and corn production per bau were 62.48 and 11.5 yokes respectively; which means that the total production was $558,466.24$ yokes for cassava and 53,568 yokes for corn. Therefore, the average per-capita for cassava was 1.03 yokes and for corn 0.10 yokes. Approaching the two year period of the 1930s, the average per-capita for cassava was 2.02 yokes and corn was 0.24 (Scheltema, 1922: 419).

Other palawija plants occupied quite large agriculture area were sweet potato, nuts, and tobacco. In 1903, the areas of the agriculture land for sweet potato and nuts were 1.796 and 1,352 bau respectively. Especially for sweet potato, in 1928, each citizen received an average of 0.24 yoke (Scheltema, 1922: 419). Tobacco in Purworedjo experienced quite good development; the number of land planted by tobacco in 1923 and 1924 was 1,063 and 1,142 bau respectively. A number of farmers also planted other plants such as soybean and sugar cane trees. In 1903, the two plants consecutively occupied areas as large as 43 and 410 bau respectively; while other palawija plants which also gave contribution to the farmers' income occupied areas as large as 12,377 bau (Fernando, 1986: 102).

In addition to the income from cultivating rice field and plantation, the farmers in Purworedjo were also familiar with the type of agriculture in their yard and garden which also contributed to their income. Gardens were planted with fruits, vegetables, and especially coconut trees. The high demand of coconut oil, both lighting and cooking, and also coconut sugar, made coconuts contain higher economical value for farmers in Purworedjo (the number of coconuts from Purworedjo were exported to Semarang in 1898 reached 23, 154 yokes. Look at Algemen Verslag Purworedjo 1899).

In line with the high commercialism due to higher demand of cash, coconut trees were much of help for the farmers in gaining profits in the form of cash. It had been general symptom at that time that farmers often pawned their coconuts to the owner of coconut oil or coconut sugar factories or to the Chinese to get some money. Thus, coconut trees could not only give income at the harvest time but also could be pawned once at a time when the need for money urged, such as to pay for the tax or to cover for daily life necessities. In 1904, farmers would receive money from $\mathrm{f} 1 \mathrm{until} \mathrm{f} 2$ by pawning one coconut tree (Scheltema, 1922: 425). The pawning of coconut trees in Purworedjo was known as odol bluluk. Bluluk was the name given by Javanese people to refer to the kernels of coconuts, while odol is the term in Javanese language which means to sell.

In 1903, the area of dry land (yard, farm, and garden) in Afdeeling Purworejo was 24,465 bau or $26 \%$ of the total agriculture land in Purworejo, while the owners of the land were as many as 29,291 farmers; therefore, the average farmer had 0.8 
bau dry oil (Gelpke, 1904: 21-22). In such large area, in 1903, Purworejo had productive coconut trees as many as 1,480,564 trees, and 1,192.28 non-yielding trees, so that the total number of coconut trees was 2,672,845 trees. The condition showed that coconut tree plantation was pretty intensive conducted in Purworejo. The price for one coconut in 1903 was $\mathrm{f}$ 0.04,- and every tree averagely produced 40 coconuts; thus, the average income per tree was $\mathrm{f} 2.5,-$.

The expansion of coconut trees planting in Purworejo in the first three decades of the twentieth century was intensively conducted. In 1917, productive coconut trees in Purworejo reached the number of 2,394,000 and the non-yielding ones was $1,575,000$, so that they made the total of $3,969,000$ with the price for one coconut as much as fo.045,- (Schletema, 1922: 427). Therefore, the income from coconut trees for each of owner experienced a quite significant increase.

Different from the price of rice, the price of coconut tended to be stable. When the regional price of coconut rose, Purworejo still had a large amount of coconut supplies which was very advantageous for the farmers, for example, in 1924, when the price of coconut reached the price of $\mathrm{f}$ 4,- per 100 (van Ginkel, 1926: 77).

Table 2. The Production of Coconut in the Villages of Purworejo District in 1923:

\begin{tabular}{c|c|c|c|c|c|c}
\hline Villages & $\begin{array}{c}\text { Productive } \\
\text { tres }\end{array}$ & $\begin{array}{c}\text { Non- } \\
\text { ielding } \\
\text { trees }\end{array}$ & Total & $\begin{array}{c}\text { The number } \\
\text { of population }\end{array}$ & $\begin{array}{c}\text { Productive } \\
\text { coconut per }\end{array}$ & $\begin{array}{c}\text { Non- } \\
\text { yielding } \\
\text { coconut } \\
\text { per }\end{array}$ \\
\hline Tanjung & 2,370 & - & 3,3370 & 957 & 3.5 & $3 \cdot 5$ \\
Wirun & 5,184 & 7,756 & 12,940 & 2,991 & 4.5 & 3 \\
Winong & 3,899 & 3,283 & 7,182 & 1,674 & 4.5 & 3.5 \\
Kunir & 3,680 & 3,151 & 6,831 & 1,578 & 4.5 & 3.5 \\
Tersidilor & 4,978 & 1,536 & 61,514 & 1,049 & 6 & 4.5 \\
\hline
\end{tabular}

Source: G. J. A., Terra, "De Voeding der Bevolking en de Erfcultuur", in Koloniaal Studiens, II, 1932, p. 584 .

The significance of coconut as the source of income for the farmers' economy in Purworejo was clearly reflected in the level of village. In 1923, the income per citizen from coconut yields in Tanjung village was as much as $\mathrm{f} 9,-;$ in Wirun village $\mathrm{f} 7,-$; in Winong village $\mathrm{f} 6,-$; in Kunir village f6,-; and in Tersidilor village $\mathrm{f12,-;}$; and every bau of yard in the village yielded an average of $\mathrm{f} 160,-$. In addition to coconut trees, other plants which grew in fertile and were pretty much of help for the farmers in fulfilling their needs of money were bamboo, betel, sugar palm, and fruits.

The economic income of Purworedjo's villagers in the beginning of the twentieth century had experienced diversification. Farmers in Purworedjo did not only depend on rice field agriculture. Rice field agriculture in Purworejo was actually a vital economic activity for the local farmers; however, considering the small area for rice field in the region due to the sugar cane plantation for the sugar 
industries in the region (Purworejo's and Rembun's Sugar Factories) and the risk of pretty high crops failure, the farmers of Purworedjo then intensified dry soil agriculture (non-rice agriculture). This enabled them to get compensataion for their economic source to fulfill their daily life necessities.

\section{Conclusion}

The farmers' society along with their limitations did not become difficult, static, and subsistent in coping with the flow of commercialism. In fact, they were able to find economic innovation through dry soil agriculture which could provide them with sufficient income. Through non-rice agriculture, the farmers were brave to take the risk of being dependent to the market development. The farmers had life skills to create advantageous alternative economic resources to support their lives in the middle of commercialism by big-scale foreign plantations.

\section{REFERENCES}

Algement Verslaag Purworejo (1882).

Algemen Verslag Purworejo 1899.

Antlov, H. (2001) Kepemimpinan Jawa: perintah halus, pemerintahan otoriter. Jakarta: Yayasan Obor.

Arminus. (1889). "Het Budget van een Javaansche Landbouwer", dalam Indische Gids, II..

Balitbang Puskur Depdiknas. (2007). Konsep Pengembangan Model Integrasi Kurikulum Pendidikan Kecakapan Hidup, Pendidikan Menengah. Jakarta: Dikdasmen.

Boeke, J.H. dan Burger, D.H. (1973).Ekonomi Dualistis: Dialog antara Boeke dan Burger. Jakarta: Bhratara.

Breman, J. (1986). Penguasaan Tanah dan Tenaga Kerja di Jawa Masa Kolonial. Jakarta: LP3ES.

Doorn, C.L. van. (1926). Schets van de Economische Ontwikkeling der Afedeeling Purworejo, Weltevreden: G. Koof \& Co.,

Fernando. (1986). "Dynamics of Peasants Economy of Java at Local Level”, dalam D.P. Chandler dan M.C. Ricklefs, Nineteent and Twentieth Century Indonesia, Victoria: Center of Southeast Asian Studies Monas University,.

Geertz, C. (1983). Involusi Pertanian: Proses Perubahan Ekologi di Indonesia, Jakarta: Bhratara.

Gelderen, J. van. (1912.) "Bevolkingdictheid en Landbouw op Java”, Koloniale Studien, II.

Gelpke, S. (1904). "Beantwording van Ewnige den Vraagpunten Betreffende het Landbouwcrediet", dalam Koloniaal Tijdschrift,.

Gilbert, J. dan Garraghan, S.J. (1957). A Guide to Historical Method. East Fortham Road and New York: Fordham University Press.

Ginkel, H. Fieves de Malines van. (1926). Verslag van Economische Toestand 
der Inlandsche Bevolking 1924, I, Wltevreden: Landsdrukerij.

Kartodirdjo, S. (1977). Memorie Serah Jabatan Jabatan 1921-1930: Jawa Tengah, Jakarta: Arsip Nasional Republik Indonesia,

Kartodirdjo, S. dan Suryo, D. (1991) Sejarah Perkebunan Di Indonesia: Kajian Sosial Ekonomi, Yogyakarta: Aditya Media.

Onderzoek naar de Mindere Welvaart der Inslandsche Bevolking op Java en Madoera, Batavia: Landsdrukkerij, 1905, IX.c.

Paulus, J. (1917), Encyclopedie van Nederlandsch Indie, 's-Gravenhage: Martinus Nijhoff,

Popkin, S.L.. (1979)Rational Peasant: The Political Economy of Rural Society in Vietnam, Berkeley: University of California.

Sajogyo dan. Collier, W.L. (1986). Budi Daya Padi di Jawa, Jakarta: Gramedia, Scheltema, A.M.P.A. (1922) "Enige Gegevens Betreffende den Economischen Toestend in de Regentschappen, van waar in 1928 de meeeste Contractkoelies", Koloniale Studien, II,

Scott, J.C. (1989). Moral Ekonomi Petani: Pergolakan dan Subsistensi di Asia Tenggara, Jakarta: LP3ES,.

Suryomihardjo, A. (1979). Pembinaan Bangsa Dan Masalah Historiografi. Jakarta: Yayasan Idayu Press..

Terra, G.J.A., "De Voeding der Bevolking en de Erfcultuur", dalam Koloniaal Studiens, II, 1932. 